\title{
DEEP-SEA DECAPOD FAUNA OF THE WESTERN MEDITERRANEAN: BATHYMETRIC DISTRIBUTION AND BIOGEOGRAPHIC ASPEGTS
}

\author{
BY \\ J. E. CARTES \\ Institut de Ciències del Mar, Passeig Nacional s/n, 08039 Barcelona, Spain
}

\begin{abstract}
ABSTRAC'T
A total of 57 bottom trawl hauls, using an OTSB-14, were carried out at depths between 862 and $2265 \mathrm{~m}$ in the Catalan Sea in 1988 and 1989. 28 species were identified including 6 Dendrobranchiata, 1 Stenopodidean, 7 Caridea, 2 Thalassinidea, 2 Palinura, 3 Anomura, and 7 Brachyura. Munidopsis tridentata, Chaceon mediterraneus and a new species of Axiidae were the most important faunistic records in this survey. Changes in the decapod crustacean fauna in the Catalan Sea were reflected by an impoverishment of species with increasing depth. The most pronounced qualitative changes in the fauna were recorded between 1000 and $1200 \mathrm{~m}$ and at around $2000 \mathrm{~m}$. The bathyal decapod fauna in the western Mediterranean is quite similar to that in the Atlantic. The most important families and genera common to both bathyal zones are the Crangonidae, Galatheidae and Geryonidae, and the genera Nematocarcinus and Stereomastis. In contrast, the tropical species Aristeus antennatus, Acanthephyra eximia, and Plesionika acanthonotus, that are of little importance in the North Atlantic, are widely distributed and frequent in the deep western Mediterranean.
\end{abstract}

\section{RÉSUMÉ}

57 chalutages benthiques, avec un chalut OTSB-14, ont été effectués en mer Catalane en 1988-1989, entre 862 et 2265 mètres de profondeur. 28 espèces ont été identifiées, à savoir: 6 Dendrobranchiata, 1 Stenopodide, 7 Caridea, 2 Thalassinidea, 2 Palinura, 3 Anomura et 7 Brachyura. Munidopsis tridentata, Chaceon mediterraneus et un nouvelle espèce d'Axiidae sont les apports faunistiques les plus importants fournis par ces prospections. Les changements dans la faune des crustacés décapodes en mer Catalane ont été marqués par un appauvrissement des espèces avec la profondeur. Les changements qualitatifs les plus prononcés dans la faune ont été enregistrés entre 1000 et $1200 \mathrm{~m}$ et vers $2000 \mathrm{~m}$. La faune bathyale de décapodes de Méditerranée occidentale et celle de l'Atlantique sont tout à fait similaires. Les familles et genres les plus importants dans les deux zones bathyales sont les Crangonidae, les Galatheidae et les Geryonidae, et les genres Nematocarcinus et Stereomastis. Par contre, les espèces tropicales Aristeus antennatus, Acanthephyra eximia et Plesionika acanthonotus, qui sont de peu d'importance dans l'Atlantique Nord, sont largement distribuées et fréquentes dans les eaux profondes de la Méditerranée occidentale.

\section{INTRODUCTION}

The deep-sea decapod crustacean fauna in the Mediterranean Sea has been only partially studied. The composition of bathyal decapod communities on the upper slope in the northwestern Mediterranean is relatively well known (Zariquiey Alvarez, 1968; Sardà \& Palomera, 1981; Abelló et al., 1988) down to 800 $\mathrm{m}$ in depth, the lower limit to operations by commercial trawlers. Information below $1000 \mathrm{~m}$ is, however, particularly scanty (Carpine, 1970b; Pérès, 1985; Abelló \& Valladares, 1988; Manning \& Holthuis, 1989). A prior study carried 
Information on deep-sea trawls carried out in the Catalan Sea over the study period

\begin{tabular}{|c|c|c|c|c|c|c|}
\hline \multirow{2}{*}{$\begin{array}{l}\text { Station } \\
\text { B85/1 }\end{array}$} & \multirow{2}{*}{$\begin{array}{c}\text { Date } \\
24 / 09 / 85\end{array}$} & \multirow{2}{*}{$\frac{\begin{array}{c}\text { Depth } \\
\text { Initial-Final })\end{array}}{1040-1020}$} & \multicolumn{2}{|c|}{ Initial situation } & \multicolumn{2}{|c|}{ Final situation } \\
\hline & & & $4057.1 \mathrm{~N}$ & $204.4 \mathrm{E}$ & $4059.1 \mathrm{~N}$ & $207.5 \mathrm{E}$ \\
\hline B85/2 & $24 / 09 / 85$ & $1280-1220$ & $4054.3 \mathrm{~N}$ & $208.5 \mathrm{E}$ & $4056.7 \mathrm{~N}$ & $211.8 \mathrm{E}$ \\
\hline B85/3 & $25 / 09 / 85$ & $1296-1322$ & $4047.4 \mathrm{~N}$ & $150.4 \mathrm{E}$ & $4045.2 \mathrm{~N}$ & $146.3 \mathrm{E}$ \\
\hline $\mathrm{B} 85 / 4$ & $25 / 09 / 85$ & $157 \bar{j}-1545$ & $4031.4 \mathrm{~N}$ & $146.5 \mathrm{E}$ & $4029.1 \mathrm{~N}$ & l $45.7 \mathrm{E}$ \\
\hline $\mathrm{B} 2 / 4$ & $30 / 07 / 87$ & $1420-1400$ & $4043.5 \mathrm{~N}$ & $146.4 \mathrm{E}$ & $4044.7 \mathrm{~N}$ & $152.6 \mathrm{E}$ \\
\hline B2/5 & $31 / 07 / 87$ & $1753-1727$ & $4020.9 \mathrm{~N}$ & $153.3 \mathrm{E}$ & $4023.4 \mathrm{~N}$ & $156.9 \mathrm{E}$ \\
\hline $\mathrm{B} 2 / 6$ & $31 / 07 / 87$ & $1267-1329$ & $4053.1 \mathrm{~N}$ & $220.0 \mathrm{E}$ & $4054.7 \mathrm{~N}$ & $211.5 \mathrm{E}$ \\
\hline $\mathrm{B} 2 / 8$ & $01 / 08 / 87$ & $1270-1357$ & $4107.3 \mathrm{~N}$ & $235.2 \mathrm{E}$ & $4102.6 \mathrm{~N}$ & $227.8 \mathrm{E}$ \\
\hline B $3 / 3$ & $25 / 06 / 88$ & $1823-1773$ & $4026.7 \mathrm{~N}$ & $200.4 \mathrm{E}$ & $4018.5 \mathrm{~N}$ & l $57.2 \mathrm{E}$ \\
\hline B $3 / 4$ & $26 / 06 / 88$ & 2163-2039 & $4045.4 \mathrm{~N}$ & $309.7 \mathrm{E}$ & $3037.7 \mathrm{~N}$ & $306.2 \mathrm{E}$ \\
\hline B3/5 & $26 / 06 / 88$ & $2266-2239$ & $4037.2 \mathrm{~N}$ & $338.0 \mathrm{E}$ & $4032.3 \mathrm{~N}$ & $344.7 \mathrm{E}$ \\
\hline $\mathrm{B} 3 / 6$ & $27 / 06 / 88$ & $1857-1819$ & $4028.9 \mathrm{~N}$ & $242.0 \mathrm{E}$ & $4032.9 \mathrm{~N}$ & $250.8 \mathrm{E}$ \\
\hline $\mathrm{B} 3 / 7$ & $27 / 06 / 88$ & $1621-1539$ & $4006.1 \mathrm{~N}$ & $251.2 \mathrm{E}$ & $4009.2 \mathrm{~N}$ & $301.0 \mathrm{E}$ \\
\hline B3 $/ 8$ & $28 / 06 / 88$ & $1737-1720$ & $4018.2 \mathrm{~N}$ & $259.9 \mathrm{E}$ & $4016.7 \mathrm{~N}$ & $254.8 \mathrm{E}$ \\
\hline $\mathrm{B} 3 / 9$ & $30 / 06 / 88$ & $2211-2193$ & $4035.8 \mathrm{~N}$ & $332.3 \mathrm{E}$ & $4038.7 \mathrm{~N}$ & $323.1 \mathrm{E}$ \\
\hline $\mathrm{B} 3 / 11$ & $02 / 07 / 88$ & $1520-1429$ & $4058.4 \mathrm{~N}$ & $224.2 \mathrm{E}$ & $4057.6 \mathrm{~N}$ & $223.3 \mathrm{E}$ \\
\hline B3/ 12 & $02 / 07 / 88$ & $1680-1574$ & $4052.6 \mathrm{~N}$ & $223.9 \mathrm{E}$ & $4057.3 \mathrm{~N}$ & $232.3 \mathrm{E}$ \\
\hline B3/15 & $03 / 07 / 88$ & $1011-946$ & $4048.9 \mathrm{~N}$ & $135.7 \mathrm{E}$ & $4055.3 \mathrm{~N}$ & $144.4 \mathrm{E}$ \\
\hline $\mathrm{B} 3 / 16$ & $04 / 07 / 89$ & $1249-1193$ & $4049.2 \mathrm{~N}$ & $150.9 \mathrm{E}$ & $4045.2 \mathrm{~N}$ & $138.8 \mathrm{E}$ \\
\hline $\mathrm{B} 3 / 17$ & $04 / 07 / 89$ & $1434-1319$ & $4043.2 \mathrm{~N}$ & $144.6 \mathrm{E}$ & $4045.8 \mathrm{~N}$ & $155.4 \mathrm{E}$ \\
\hline B3/18 & $04 / 07 / 88$ & $1753-1779$ & $4038.6 \mathrm{~N}$ & $206.0 \mathrm{E}$ & $4031.5 \mathrm{~N}$ & $201.6 \mathrm{E}$ \\
\hline B3/19 & $05 / 07 / 89$ & $1827-1883$ & $4031.9 \mathrm{~N}$ & $216.0 \mathrm{E}$ & $4026.4 \mathrm{~N}$ & $209.9 \mathrm{E}$ \\
\hline $\mathrm{B} 3 / 20$ & $05 / 07 / 89$ & $1772-1899$ & $4017.2 \mathrm{~N}$ & $207.2 \mathrm{E}$ & $4024.6 \mathrm{~N}$ & $214.4 \mathrm{E}$ \\
\hline $\mathrm{B} 3 / 21$ & $06 / 07 / 88$ & $1735-1680$ & $4013.2 \mathrm{~N}$ & $225.6 \mathrm{E}$ & $4014.1 \mathrm{~N}$ & $212.1 \mathrm{E}$ \\
\hline B $3 / 22$ & $06 / 07 / 88$ & $1631-1578$ & $4005.8 \mathrm{~N}$ & $204.9 \mathrm{E}$ & $4009.2 \mathrm{~N}$ & $213.9 \mathrm{E}$ \\
\hline B $3 / 23$ & $06 / 07 / 88$ & $1439-1394$ & $4002.9 \mathrm{~N}$ & $214.3 \mathrm{E}$ & $4002.8 \mathrm{~N}$ & $204.4 \mathrm{E}$ \\
\hline B3/24 & $07 / 07 / 88$ & $980-1019$ & $3952.8 \mathrm{~N}$ & $224.3 \mathrm{E}$ & $3951.6 \mathrm{~N}$ & $213.3 \mathrm{E}$ \\
\hline B3/25 & $07 / 07 / 88$ & $1224-1184$ & $3957.5 \mathrm{~N}$ & $218.1 \mathrm{E}$ & $3955.0 \mathrm{~N}$ & $208.9 \mathrm{E}$ \\
\hline B3/26 & $08 / 07 / 88$ & $1752-1737$ & $4019.9 \mathrm{~N}$ & l $53.3 \mathrm{E}$ & $4026.6 \mathrm{~N}$ & $158.6 \mathrm{E}$ \\
\hline B3/27 & $10 / 07 / 88$ & $1069-1062$ & $4111.1 \mathrm{~N}$ & $232.1 \mathrm{E}$ & $4107.5 \mathrm{~N}$ & $227.0 \mathrm{E}$ \\
\hline b3/28 & $11 / 07 / 89$ & $1927-1820$ & $4020.2 \mathrm{~N}$ & $243.6 \mathrm{E}$ & $4026.4 \mathrm{~N}$ & $237.7 \mathrm{E}$ \\
\hline $\mathrm{B} 4 / 1$ & $26 / 07 / 88$ & $1029-908$ & $4122.4 \mathrm{~N}$ & $311.6 \mathrm{E}$ & $4121.5 \mathrm{~N}$ & $318.4 \mathrm{E}$ \\
\hline $\mathrm{B} 4 / 1$ & $26 / 07 / 88$ & $2107-1941$ & $4113.5 \mathrm{~N}$ & $323.4 \mathrm{E}$ & $4116.7 \mathrm{~N}$ & $328.4 \mathrm{E}$ \\
\hline $\mathrm{B} 4 / 3$ & $27 / 07 / 88$ & $2188-2156$ & $4105.3 \mathrm{~N}$ & $321.2 \mathrm{E}$ & $4108.5 \mathrm{~N}$ & $332.4 \mathrm{E}$ \\
\hline $\mathrm{B} 4 / 4$ & $28 / 07 / 88$ & $2071-1880$ & $4056.7 \mathrm{~N}$ & $300.7 \mathrm{E}$ & $4105.0 \mathrm{~N}$ & $306.7 \mathrm{E}$ \\
\hline $\mathrm{B} 4 / 6$ & $28 / 07 / 88$ & $1900-1746$ & $4112.6 \mathrm{~N}$ & $307.5 \mathrm{E}$ & $4114.2 \mathrm{~N}$ & $317.3 \mathrm{E}$ \\
\hline B $4 / 7$ & $29 / 07 / 88$ & $2221-2196$ & $4111.2 \mathrm{~N}$ & $336.9 \mathrm{E}$ & $4105.1 \mathrm{~N}$ & $329.4 \mathrm{E}$ \\
\hline $\mathrm{B} 4 / 8$ & $29 / 07 / 88$ & $1916-1762$ & $4106.5 \mathrm{~N}$ & $259.4 \mathrm{E}$ & $4107.1 \mathrm{~N}$ & $246.6 \mathrm{E}$ \\
\hline B $4 / 9$ & $30 / 07 / 88$ & $1816-1796$ & $4049.6 \mathrm{~N}$ & $232.5 \mathrm{E}$ & $4044.0 \mathrm{~N}$ & $228.6 \mathrm{E}$ \\
\hline $\mathrm{B} 4 / 10$ & $30 / 07 / 88$ & $1284-1246$ & $4052.6 \mathrm{~N}$ & $203.1 \mathrm{E}$ & $4056.5 \mathrm{~N}$ & $212.5 \mathrm{E}$ \\
\hline $\mathrm{B} 4 / 11$ & $31 / 07 / 88$ & $1531-1446$ & $4059.3 \mathrm{~N}$ & $226.4 \mathrm{E}$ & $4103.5 \mathrm{~N}$ & $237.2 \mathrm{E}$ \\
\hline $\mathrm{B} 4 / \mathrm{I} 2$ & $31 / 07 / 89$ & $1358-1247$ & $4106.0 \mathrm{~N}$ & $232.6 \mathrm{E}$ & $4102.6 \mathrm{~N}$ & $224.1 \mathrm{E}$ \\
\hline $\mathrm{B} 5 / 2$ & $25 / 10 / 88$ & $1609-1562$ & $4020.5 \mathrm{~N}$ & $142.5 \mathrm{E}$ & $4028.0 \mathrm{~N}$ & $147.2 \mathrm{E}$ \\
\hline $\mathrm{B} 5 / 3$ & $25 / 10 / 88$ & $1779-1744$ & $4028.5 \mathrm{~N}$ & $158.4 \mathrm{E}$ & $4020.7 \mathrm{~N}$ & $154.0 \mathrm{E}$ \\
\hline $\mathrm{B} 5 / 4$ & $26 / 10 / 88$ & $1100-1054$ & $3954.5 \mathrm{~N}$ & $221.6 \mathrm{E}$ & $3950.5 \mathrm{~N}$ & $207.1 \mathrm{E}$ \\
\hline $\mathrm{B} 5 / 6$ & $26 / 10 / 89$ & $1800-1694$ & $4009.4 \mathrm{~N}$ & $159.0 \mathrm{E}$ & $4006.8 \mathrm{~N}$ & $149.9 \mathrm{E}$ \\
\hline
\end{tabular}




\begin{tabular}{lccccccc}
\hline Station & Date & $\begin{array}{c}\text { Depth } \\
\text { (Initial-Final) }\end{array}$ & \multicolumn{2}{c}{ Initial situation } & \multicolumn{2}{c}{ Final situation } \\
\hline B5/7 & $27 / 10 / 88$ & $1754-1698$ & $4019.3 \mathrm{~N}$ & $153.3 \mathrm{E}$ & $4027.3 \mathrm{~N}$ & $154.4 \mathrm{E}$ \\
$\mathrm{B} 5 / 8$ & $27 / 10 / 88$ & $1680-1575$ & $4030.7 \mathrm{~N}$ & $147.6 \mathrm{E}$ & $4036.9 \mathrm{~N}$ & $149.1 \mathrm{E}$ \\
$\mathrm{B} 5 / 9$ & $27 / 10 / 88$ & $1234-1196$ & $4039.4 \mathrm{~N}$ & $136.4 \mathrm{E}$ & $4045.9 \mathrm{~N}$ & $139.3 \mathrm{E}$ \\
$\mathrm{B} 5 / 10$ & $27 / 10 / 88$ & $1014-1004$ & $4050.6 \mathrm{~N}$ & $144.1 \mathrm{E}$ & $4053.9 \mathrm{~N}$ & $145.0 \mathrm{E}$ \\
$\mathrm{B} 5 / 11$ & $28 / 10 / 88$ & $1036-994$ & $4053.3 \mathrm{~N}$ & $144.6 \mathrm{E}$ & $4055.6 \mathrm{~N}$ & $152.3 \mathrm{E}$ \\
$\mathrm{B} 5 / 13$ & $28 / 10 / 88$ & $961-1087$ & $4059.5 \mathrm{~N}$ & $158.5 \mathrm{E}$ & $4057.4 \mathrm{~N}$ & $207.5 \mathrm{E}$ \\
$\mathrm{B} 5 / 14$ & $28 / 10 / 88$ & $1158-1034$ & $4056.2 \mathrm{~N}$ & $206.5 \mathrm{E}$ & $4103.0 \mathrm{~N}$ & $211.3 \mathrm{E}$ \\
$\mathrm{B} 5 / 15$ & $29 / 10 / 88$ & $1110-1035$ & $4101.2 \mathrm{~N}$ & $213.2 \mathrm{E}$ & $4103.6 \mathrm{~N}$ & $218.1 \mathrm{E}$ \\
$\mathrm{B} 5 / 16$ & $29 / 10 / 88$ & $1120-1008$ & $4104.2 \mathrm{~N}$ & $220.2 \mathrm{E}$ & $4106.2 \mathrm{~N}$ & $222.5 \mathrm{E}$ \\
$\mathrm{B} 5 / 17$ & $29.10 / 88$ & $861-1100$ & $4107.5 \mathrm{~N}$ & $227.3 \mathrm{E}$ & $4112.6 \mathrm{~N}$ & $232.4 \mathrm{E}$ \\
$\mathrm{B} 5 / 18$ & $29 / 10 / 88$ & $1524-1479$ & $4102.9 \mathrm{~N}$ & $235.9 \mathrm{E}$ & $4100.8 \mathrm{~N}$ & $231.2 \mathrm{E}$ \\
$\mathrm{B} 5 / 19$ & $30 / 10 / 88$ & $1795-1740$ & $4104.1 \mathrm{~N}$ & $253.4 \mathrm{E}$ & $4105.6 \mathrm{~N}$ & $250.3 \mathrm{E}$ \\
& & & & & & & \\
$\mathrm{SP} 89 / 2$ & $16 / 10 / 89$ & $862-989$ & $4049.8 \mathrm{~N}$ & $133.8 \mathrm{E}$ & $4051.7 \mathrm{~N}$ & $140.9 \mathrm{E}$ \\
$\mathrm{SP} 89 / 3$ & $17 / 10 / 89$ & $1772-1808$ & $4025.8 \mathrm{~N}$ & $159.8 \mathrm{E}$ & $4020.9 \mathrm{~N}$ & $201.2 \mathrm{E}$ \\
$\mathrm{SP} 89 / 5$ & $18 / 10 / 89$ & $1478-1547$ & $4012.1 \mathrm{~N}$ & $139.7 \mathrm{E}$ & $4004.5 \mathrm{~N}$ & $138.4 \mathrm{E}$ \\
\hline
\end{tabular}

out in the Catalan Sea by Abelló \& Valladares (1988) furnished qualitative data for the zone located between 1020 and $2011 \mathrm{~m}$.

The present paper contributes new data in an effort to characterize the bathyal decapod crustacean fauna in the Mediterranean based on a sampling that provided uniform coverage of the deep-sea slope between 862 and $2265 \mathrm{~m}$ by means of bottom trawls (OTSB-14). Aspects of the depth and biogeographic distribution of deep-sea decapods are discussed and compared with the data available for other deep-sea regions (Kensley, 1968; Crosnier \& Forest, 1973; Lagardère, 1977; Wenner \& Boesch, 1979; Haedrich et al., 1980; de Saint Laurent, 1985; Markle et al., 1988; and others).

\section{MATERIAL AND METHODS}

A total of 57 bottom trawl hauls were carried out at depths between 862 and $2265 \mathrm{~m}$ in the Catalan Sea in 1988 and 1989 (table I). The maximum depth in this region is around $2300 \mathrm{~m}$.

The sampling gear employed was an OTSB-14 bottom trawl equipped with two doors and a single trawl warp (Merrett \& Marshall, 1981; Sulak, unpubl.). The end of the net was lined with a $6-\mathrm{mm}$ mesh inside codend liner. All samples were taken on board the R/V "García del Cid" (1500 HP; $38 \mathrm{~m}$ ).

The samples were preserved in $70 \%$ alcohol. All specimens were identified at the laboratory. In the systematic list of species the classification system of Bowman \& Abele (1982) was adopted.

A further four samples were included when calculating the probability of occurrence of species by depth stratum. These additional samples were collected in 1985, and their faunistic results were published by Abello \& Valladares, 1988. 


\section{RESULTS}

A total of 28 species was identified (table II) and included 6 Dendrobranchiata, 1 Stenopodidean, 7 Caridea, 2 Thalassinidea, 2 Palinura, 3 Anomura, and 7 Brachyura. Seven of these species are mesopelagic and bathypelagic. This is the case of Gennadas elegans, all the Sergestidae, Acanthephyra pelagica, and Pasiphaea multidentata.

\section{TABLE II}

Systematic list of decapod crustacean species collected over the study period according to the classification system of Bowman \& Abele (1982)

ORDER DECAPODA

Suborder DENDEOBRANCHIATA

Superfamily Penacoidea

Family Aristeidae

Gennadas elegans (S.I. Smith, 1884)

Aristeus antennatus (Risso, 1816)

Superfamily Sergestoidea

Family Sergestidae

Sergestes arcticus Kröyer, 1855

Sergestes henseni (Ortmann, 1893)

Sergestes sargassi (Ortmann, 1893)

Sergia robusta (S.I. Smith, 1882)

Suborder PLEOCYEMATA

Infraorder STENOPODIDEA

Family Stenopodidae

Richardina fredericii Lo Bianco, 1903

Infraorder CARIDEA

Family Oplophoridae

Acanthephyra eximia S.I. Smith, 1886

Acanthephyra pelagica (Risso, 1816)

Family Nematocarcinidae

Nematocarcinus exilis (Bate, 1888)

Family Pasiphaeidae

Pasiphaea multidentata Esmark, 1866

Family Pandalidae

Plesionika acanthonotus (S.I. Smith, 1882)

Family Crangonidae

Pontocaris lacazei (Gourret, 1887)

Pontophilus norvegicus (M. Sars, 1861)
Infraorder PALINURA

Family Polychelidae

Polycheles typhlops Heller, 1862

Stereomastis sculpta (S.I. Smith, 1880)

Infraorder ANOMURA

Family Paguridae

Pagurus alatus Fabricius, 1775

Family Galatheidae

Mumida tenuimana G.O. Sars, 1872

Munidopsis tridentata (Esmark, 1857)

Infraorder BRACHYURA

Section ARCHEOBRACHYURA

Family Homolidae

Paromola cuvieri (Risso, 1816)

Section OXYRHYNCHA

Family Majidae

Dorhynchus thomsoni Thomson, 1873

Macropodia longipes (A. Milne Edwards \& Bouvier, 1899)

\section{Section BRACHYRHYNCHA}

Family Geryonidae

Geryon longipes A. Milne Edwards, 1881

Chaceon mediterraneus Manning \& Holthuis, 1989

Family Portunidae

Macropipus tuberculatus (Roux, 1830)

Family Xanthidae

Monodaeus couchii (Couch, 1851)

Infraorder THALASSINIDEA

Family Axiidae

Calocaris macandreae Bell, 1864

Axiidae unidentified 
Several of the species identified were noteworthy on account of their rarity among the Mediterranean deep-sea decapods. The anomuran Munidopsis tridentata was first reported in the Mediterranean at between 1545 and $1580 \mathrm{~m}$ by Abelló \& Valladares (1988). In the present study a second individual was taken in a haul carried out between 908 and $1027 \mathrm{~m}$, associated with a gorgonian of the species Paramuricea macrospina (Koch, 1882). The specimen is an adult male with a carapace length of $3.6 \mathrm{~mm}$ (from the orbit to the posterior dorsal edge of the carapace).

Two individuals of the brachyuran Chaceon mediterraneus were collected in two hauls carried out over the deepest part of the lower slope below $1900 \mathrm{~m}$. This depth would appear to be the upper limit to the depth range of this species (Della Croce et al., 1988; Manning \& Holthuis, 1989), which, on the basis of available information, ranges down to $2830 \mathrm{~m}$. The two individuals taken were both ovigerous females. This is the first record of this species from Iberian waters (Cartes, 1993) and the third report from the Mediterranean Sea, where the species seems to be endemic.

A new species of the family Axiidae, of which the description is currently in preparation (de Saint Laurent, personal communication), is particularly important, because it may constitute a new genus endemic to the Mediterranean. Four specimens were caught at depths from 1478 to $1927 \mathrm{~m}$. The species inhabits the lower slope at great depth.

Mediterranean deep-sea species now for the first time found below $1000 \mathrm{~m}$ are the stenopodid Richardina fredericii, the anomuran Pagurus alatus (sensu Ingle, 1985), and the brachyurans Macropodia longipes and Monodaeus couchii. In addition, the results of this study have slightly extended the known depth ranges of nearly all the species (table III) (see Abelló \& Valladares, 1988).

On the whole, the depth ranges of all the species are rather broad (table III), but many of the species proved to be commonly found only over a much narrower depth range.

\section{DISCUSSION}

Changes in the species composition of the decapod crustacean fauna in the Catalan Sea consist basically in a decrease of the number of species with depth (fig. 1). The most pronounced qualitative changes in the fauna were recorded between 1000 and $1200 \mathrm{~m}$ and at around $2000 \mathrm{~m}$. Species substitution was not particularly marked, because the number of species was very low. These boundaries also corresponded to the boundaries for changes in the abundance of the dominant species and community structure. In quantitative terms, the most important boundary recorded was at 1200-1300 m (Cartes, 1991), which separated the decapod communities dwelling on the middle slope from these on the lower slope.

The species most likely to be present on the middle slope (between 862 and $1349 \mathrm{~m}$ ) were Aristeus antennatus, Plesionika acanthonotus, Polycheles typhlops, and 


\section{TABLE III}

Depth range and percentage relative frequency by $200 \mathrm{~m}$ depth stratum for decapod crustacean species on the slope in the Catalan Sea

\section{Depth stratum (m)}

Depth 862-1149 1150-1349 1350-1549 1550-1749 1750-1949 1950-2261 range $(\mathrm{m})$

\begin{tabular}{|c|c|c|c|c|c|c|c|}
\hline No. of trawls & & 14 & 9 & 7 & 13 & 11 & 7 \\
\hline G. elegans & $862-2261$ & 50.0 & 77.8 & 71.4 & 84.6 & 36.3 & 42.9 \\
\hline A. antennatus & $862-2261$ & 100.0 & 100.0 & 100.0 & 100.0 & 90.9 & 100.0 \\
\hline S. arcticus & $862-2188$ & 42.9 & 55.5 & 14.3 & 30.8 & - & 28.6 \\
\hline S. henseni & $1184-1224$ & - & 11.1 & - & - & - & - \\
\hline S. sargassi & $982-1036$ & 7.1 & - & - & - & - & - \\
\hline S. robusta & $862-2261$ & 71.4 & 77.8 & 67.2 & 84.6 & 72.8 & 100.0 \\
\hline R. fredericii & $1035-1110$ & 7.1 & $-\cdots$ & - & - & - & - \\
\hline A. eximia & $862-2261$ & 100.0 & 100.0 & 100.0 & 100.0 & 100.0 & 100.0 \\
\hline A. pelagica & $862-2261$ & 50.0 & 55.6 & 85.7 & 76.9 & 63.6 & 85.7 \\
\hline $\mathcal{N}$. exilis & $1391-2261$ & - & 33.3 & 42.9 & 100.0 & 100.0 & 100.0 \\
\hline P. multidentata & $862-2261$ & 57.1 & 77.8 & 71.4 & 61.5 & 63.7 & 71.4 \\
\hline P. acanthonotus & $862-1680$ & 100.0 & 88.9 & 71.4 & 7.7 & - & - \\
\hline P. lacazei & $862-1041$ & 14.3 & - & - & - & - & - \\
\hline P. norvegicus & $862-2261$ & 100.0 & 88.9 & 100.0 & 100.0 & 100.0 & 42.9 \\
\hline C. macandreae & $862-1675$ & 71.4 & 33.3 & 42.9 & 7.7 & - & $\cdots$ \\
\hline Unid. Axiidae & $1478-1927$ & -. & - & 14.3 & 7.7 & 9.1 & $\ldots$ \\
\hline P. typhlops & $862 \cdot 1927$ & 100.0 & 77.8 & 57.1 & 46.2 & 9.1 & - \\
\hline S. sculpia & $1054-2261$ & 21.4 & 88.9 & 100.0 & 100.0 & 100.0 & 100.0 \\
\hline$P$. alatus & 862-1096 & 35.7 & $\ldots$ & - & -. & - & - \\
\hline M. tenuimana & $862-1899$ & 100.0 & 100.0 & 100.0 & 100.0 & 100.0 & - \\
\hline$M$. tridentata & $908-1580$ & 7.1 & - & - & 7.7 & - & - \\
\hline P. cuvieri & $862-1165$ & 50.0 & - & - & - & - & - \\
\hline$M$. longipes & $946-1249$ & 7.1 & 11.1 & 14.3 & - & - & - \\
\hline D. thomsoni & $980-2211$ & 28.6 & 33.3 & - & - & - & 14.3 \\
\hline M. tuberculatus & $908-1041$ & 7.1 & - & - & - & - & - \\
\hline G. longipes & $862-1895$ & 92.9 & 88.9 & 28.6 & 30.8 & 27.3 & - \\
\hline Ch. mediterraneus & $1941-2221$ & - & - & - & - & - & 28.6 \\
\hline M. couchii & $908-1120$ & 14.3 & - & - & - & - & - \\
\hline
\end{tabular}

Geryon longipes, along with Munida tenuimana and Pontophilus norvegicus, which were also common down to 1900-2000 m. The characteristic species on the lower slope (between 1350 and $2261 \mathrm{~m}$ ) were Acanthephyra eximia, Nematocarcinus exilis, and Stereomastis sculpla. The depth ranges for all these species are quite broad, though the depth ranges in which the species populations are abundant are in fact narrower (Cartes \& Sardà, in press).

Pontocaris lacazei, Pagurus alatus, Paromola cuvieri, Macropodia longipes, Macropipus tuberculatus, and Monodaeus couchii attained in this zone the deepest part of their bathymetric distribution. These species are typical upper slope-dwellers (Abelló et al., 1988) being uncommon below $1000 \mathrm{~m}$.

The rare species Richardina fredericii, Munidopsis tridentata, and the unidentified axiid species made up another group of uncommon species. 


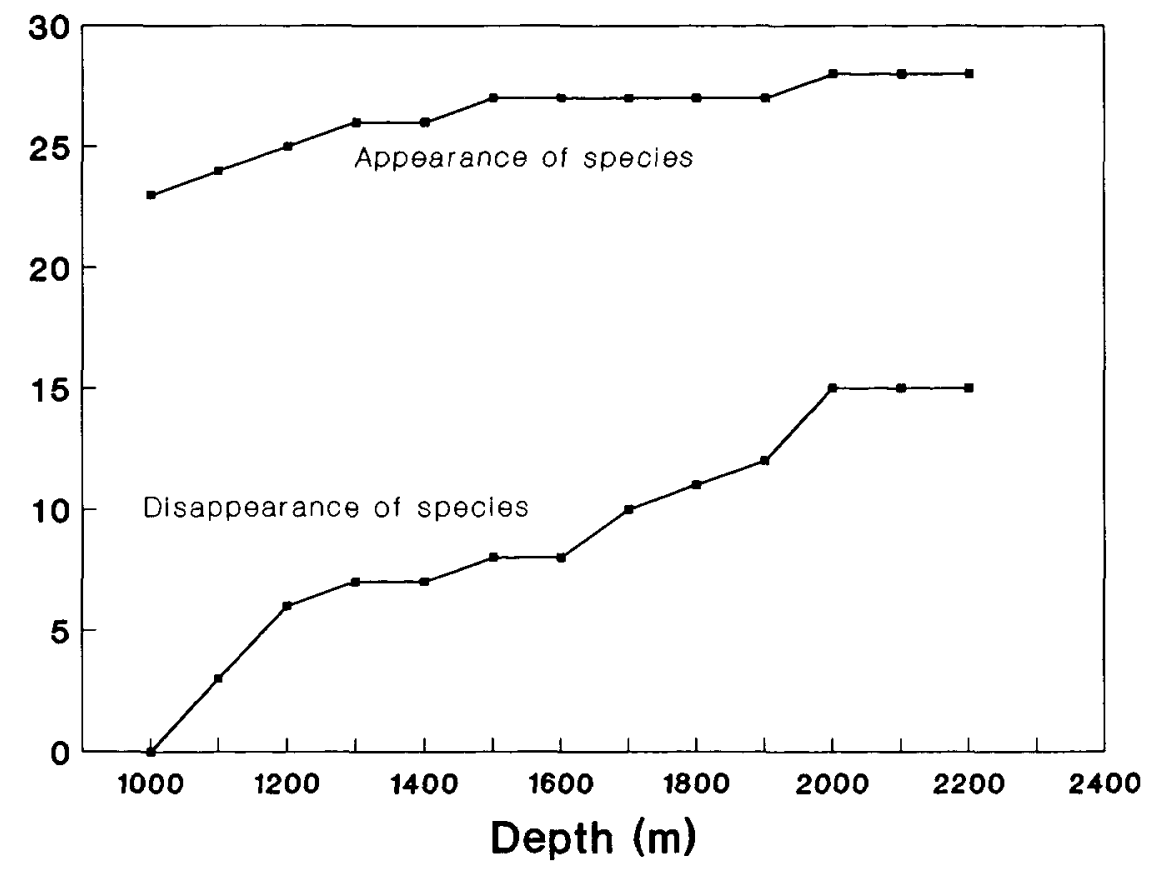

Fig. 1. Cumulative number of appearances and disappearances of species on the slope in the deep-sea region in the Catalan Sea.

The occurrence of benthopelagic species was irregular on the slope, possibly because of the restricted sampling effectiveness of the OTSB-14 gear (Cartes, 1991; Cartes \& Sardà, in press). Even so, Sergestes arcticus was more common on the middle slope; Pasiphaea multidentata, Gennadas elegans, and Sergia robusta failed to display any clear trend; and Acanthephyra pelagica was chiefly present on the lower slope (Abelló et al., 1988; Cartes, 1991).

Changes in the composition of the Mediterranean decapod fauna below 2265 $m$ are probably minor. In fact, the only record of new species at great depth was that of the brachyuran Zariquieyon inflatus, which was taken at around $2830 \mathrm{~m}$ (Manning \& Holthuis, 1989). The dominant species at these depths are probably Acanthephyra eximia and Stereomastis sculpta (see Carpine, 1970b; Fredj \& Laubier, 1985) along with $\mathcal{N}$. exilis and Chaceon mediterraneus.

A comparison of the species composition of the deep-sea decapod fauna in the Mediterranean and that in other geographic regions is difficult on account of existing systematic uncertainties and the general scarcity of data. Nevertheless, affinity with Atlantic deep-sea decapods is high with respect to families, genera, and even species, probably because of a common origin of the fauna occupying the deep-sea habitat (Menzies et al., 1973; Lipps \& Hickman, 1982). The origin of the Mediterranean deep-sea fauna would appear to date back to 
recent recolonization from the Atlantic in the Pliocene-Pleistocene after the Messinian salinity crisis in which nearly all benthic marine species became extinct (Pérès, 1985). This explains the high affinity between deep-sea decapods in the Mediterranean and the Atlantic (Carpine, 1970a; Abelló \& Valladares, 1988). Moreover, the Mediterranean deep-sea fauna is poorer in number of species than the Atlantic deep-sea fauna (Pérès, 1985), and this applies equally to decapod crustaceans (Cartes, 1991). The historical factors referred to above, together with constant temperature, the geographic and hydrological barrier represented by the Strait of Gibraltar, and the existing oligotrophy, explain the low level of species diversity in the Mediterranean deep-sea fauna, the absence of certain Atlantic stenothermal species and even families (Fredj \& Laubier, 1985), and the small number of endemic species in the Mediterranean. In the deep-sea decapod fauna so far only the brachyurans Chaceon mediterraneus Manning \& Holthuis, 1989 and Zariquieyon inflatus Manning \& Holthuis, 1989 seem to be endemic; to these can be added the undescribed Axiid species caught on the present series of trawls.

The decapod fauna on the continental slope in the western Mediterranean is quite similar to that in the Atlantic, especially to that in the Bay of Biscay (Lagardère, 1973, 1977). The same species, or the same genera are dominant on the deep-sea bottoms of the two areas, although certain major species are not present in the Mediterranean, e.g. Dichelopandalus bonnieri, Psathyrocaris infirma, Glyphocrangon sp., Neolithodes grimaldii, Parapagurus pilosimanus. The affinity between the Mediterranean deep-sea decapods and the decopods in other areas in the Atlantic at higher latitudes is not as marked. This is the case of the southern British Isles, available data on the decapod fauna of which refer to deep-sea brachyurans (Shelton \& Dooley, 1982; Rice \& Hartnoll, 1983; Attrill et al., 1991), anomurans of the genus Munida (Rice \& de Saint Laurent, 1986), polychelids (Bernard, 1953) and mesopelagic and bathypelagic species (Foxton, 1972; Fasham \& Foxton, 1979; Hargreaves, 1984). Overall, the species in this region exhibit less affinity to the Mediterranean than those in the Bay of Biscay, in spite of the relative proximity of these two Atlantic regions. In this respect, the Iberian region in the Bay of Biscay is the northernmost limit in the $\mathrm{NE}$ Atlantic for a number of subtropical species, e.g. Plesionika martia, P. acanthonotus, and Aristeus antennatus (see Zariquiey-Alvarez, 1968).

The situation is similar in the Northwest Atlantic. Affinity with the Mediterranean decapod fauna is lower in the more northern areas, Nova Scotia (Markle et al., 1988) or New England (Haedrich et al., 1975, 1980) than it is further south (Middle Atlantic Bight), where the presence of more species common to the Mediterranean fauna, like Acanthephyra eximia and Plesionika acanthonotus and certain penaeids, augments the degree of affinity (Wenner \& Boesch, 1979).

Briefly, the most important species or groups common to both the Atlantic and Mediterranean bathyal zones are species of the families Crangonidae and 
Galatheidae, the genera Nematocarcinus and Stereomastis (Wenner, 1982), along with geryonid brachyurans (Manning \& Holthuis, 1981, 1989).

In contrast, certain tropical species that are absent or of little importance in the North Atlantic are widely distributed in the western Mediterranean. Thus, for instance, the species Aristeus antennatus, Acanthephyra eximia, and Plesionika acanthonotus are already absent from the Bay of Biscay (Lagardère, 1977). The Mediterranean represents the northernmost distributions of these tropical or subtropical species, which are the most characteristic distinguishing deep-sea species in the Catalan Sea with respect to neighbouring regions of the Atlantic at the same latitude. Furthermore, these species are dominant components of the decapod crustacean communities in terms of both abundance and biomass (Cartes, 1991).

In addition, entire families of characteristic deep-sea decapods like the Glyphocrangonidae, Lithodidae, and Chirostylidae have not been found in the Mediterranean.

Very few specific data exist concerning the distribution and abundance of tropical deep-sea natantian decapod species in the Eastern Atlantic. That fauna is characterized by high diversity of species of such genera as Acanthephyra, Nematocarcinus, and Plesionika and the penaeoideans (Crosnier \& Forest, 1973). Several species of Acanthephyra are deep-sea dwellers and are abundant in the region, e.g. A. eximia and $A$. acanthitelsonis. Various species, like Plesionika acanthonotus and $A$. eximia, are also common to the Western Atlantic. Tropical deepsea benthic decapods present their own characteristics as compared to the decapod fauna in the higher latitudinal regions, such as diversification of the families Oplophoridae and Pandalidae, and this also holds true for the middle slope (Macpherson, 1991) or deepers zones (Kensley, 1981) in subtropical regions.

The affinity between Atlantic and Mediterranean abyssal decapods is very low; the species of the genus Nematocarcinus are the only common group (Kensley, 1968; Gore, 1982, 1983, 1985; de Saint Laurent, 1985; Domanski, 1986). The existence of an abyssal fauna in the Mediterranean has been called into question (Pérès, 1985). The most important feature characterizing the Mediterranean deep-sea zone is the pronounced physical stability of the water masses at a constant temperature of $12.7-12.9^{\circ} \mathrm{C}$ and a constant salinity of $38.4-38.5 \%$ at depths below $200 \mathrm{~m}$ (Hopkins, 1985). Mediterranean bathyal decapod species that are Atlantic in origin have been able to adapt to the high water temperature, since in the Atlantic bathyal zone these same species dwell at 2-6 ${ }^{\circ} \mathrm{C}$ (Wenner \& Boesch, 1979). In contrast, Atlantic abyssal and bathypelagic species are nearly entirely absent from the Mediterranean.

Despite the stability of the Mediterranean deep-sea environment, the study has highlighted the existence of bathymetric zonation and species succession, unlike the case of the echinoderms, for instance, in which eurybathic species predominate (Alvà, 1987). In view of the environmental stability, the species 
succession among decapods would appear to be conditioned by other factors, chiefly of trophic origin (Cartes, 1991).

\section{ACKNOWLEDGEMENTS}

The author expresses his appreciation to all members of the deep-sea research programs "Batimar" and "Abismar" (CICYT-CSIC) for their help. Thanks are also due to my colleagues Drs. F. Sardà, P. Abelló and E. Macpherson of the ICM in Barcelona, and to Dr. R. B. Manning for their help in the identification of several species, and to R. Sacks who prepared the English translation of this paper.

\section{REFERENCES}

Abelló, P. \& F. J. Valladares, 1988. Bathyal decapod crustaceans of the Catalan Sea (Northwestern Mediterranean). Mésogée, 48: 97-102.

Abelló, P., F. J. Valladares \& A. Castellon, 1988. Analysis of the structure of decapod crustacean assemblages off Catalan coast (North-West Mediterranean). Mar. Biol., 98: 39-49.

Alvì, V., 1987. Equinodermos batiales de la cubeta catalonobalear (Mediterráneo Noroccidental). Misc. Zool., 11: 202-211.

Attrill, M.J., R. G. Hartnoll \& A. L. Rige, 1991. Aspects of the biology of the deep-sea crab Geryon trispinosus from the Porcupine Seabight. Journ. mar. biol. Assoc. U. K., 71: 311-328.

Bernard, F., 1953. Decapoda Eryonidae (Eryoneicus et Willemoesia). Dana Rep., 37: 1-93.

Bowman, T. E. \& L. G. Abele, 1982. Classification of recent Crustacea. In: D. E. Bliss (ed.), The biology of Crustacea, 1: 1-27.

Carpine, C., 1970a. Ecologie de l'étage bathyal dans la Méditerranée occidentale. Mém. Inst. Océan. Monaco, 2: 1-146.

- - 1970b. Une expérience de chalutage profond (recherche de la "Caravelle" engloutie au large de Nice). Bull. Inst. Océanogr. Monaco, 69 (1408): 1-16.

Cartes, J. E., 1991. Análisis de las comunidades y estructura trófica de los Crustáceos Decápodos batiales del Mar Catalán. Tesis, Univ. Politécnica de Catalunya, 627 pp.

--, 1993. New records of the deep-sea crab Chaceon mediterraneus Manning \& Holthuis, 1989 in the western Mediterranean. Crustaceana, 64 (2): 221-225.

Cartes, J. E. \& Sardà, in press. Abundance and diversity of Decapod Crustaceans in the deepCatalan Sea (western Mediterranean). Journ. nat. Hist. London.

Crosnier, A. \& J. Forest, 1983. Les crevettes profondes de l'Atlantique oriental tropical. Faune Tropicale, 19: 1-409.

Della Croce, N., N. Drago \& G. Flocchini, 1988. Ricerche biologiche e geofisiche. Campagna oceanografica N/R "Minerva" (14-31.08.1987). Ins. Sc. Amb. Mar. Univ. Genova, Rapp. Tec, 24: 1-10.

Domanski, P., 1986. The near-bottom shrimp faunas (Decapoda: Natantia) at two abyssal sites in the Northeast Atlantic Ocean. Mar. Biol., 93: 171-180.

Fasham, M. J. R. \& P. Foxton, 1979. Zonal distribution of pelagic Decapoda (Crustacea) in the eastern north Atlantic and its relation to the physical oceanography. Journ. Exp. Mar. Biol. Ecol., 37: 225-253.

Foxton, P., 1972. Observations on the vertical distribution of the genus Acanthephyra (Crustacea: Decapoda) in the eastern North Atlantic, with particular reference to species of the "purpurea" group. Proc. Roy, soc. Edinburgh, (B) 73 (30): 301-313.

Fredj, G. \& L. Laubier, 1985. The deep Mediterranean benthos. In: M. Moraitou-AposTOlopoulou \& V. Kiortsis (eds), Mediterranean Marine Ecosystems: 109- 146.

Gore, R. H., 1983. Notes on rare species of Munidopsis (Anomura: Galatheidae) and Ethusina (Brachyura: Dorippidae) collected by the USNS "Bartlett" in the Venezuela Basin, Caribbean Sea. Proceedings Acad. nat. Sci. Philadelphia, 135: 200-217. 
- - 1984. Notes on abyssal lobsters, genus Willemoesia (Palinura, Polychelidae) collected by USNS "Bartlett" from the Venezuela Basin, Caribbean Sea. Proceedings. Acad. nat. Sci. Philadelphia, 136: 1-11.

,-- 1985 . Abyssobenthic and abyssopelagic Penacoidean shrimp (families Aristeidae and Penaeidae) from the Venezuela Basin, Caribbean Sea. Crustaceana, 49 (2): 120-138.

Haedrich, R. L., G. T. Rowe \& P. T. Polloni, 1975. Zonation and faunal composition of epibenthic populations on the continental slope south of New England. Journ. Mar. Res., 33: 191-212.

$--,-\ldots, \ldots, 1980$. The megabenthic fauna in the deep sea south of New England. U.S.A. Mar. Biol., 57: 165-179.

Hargreaves, P. M., 1984. The distribution of Decapoda (Crustacea) in the open ocean and nearbottom over an adjacent slope in the northern North-east Atlantic ocean during autumn 1979. Journ. Mar. Biol. Assoc. U.K., 64: 829-857.

Hopkins, T. S., 1985. Physics of the Sea. In: R. Margalef (ed.), Key environments: Western Mediterranean: 100-125.

Ingle, R. W., 1985. Northeastern Atlantic and Mediterranean hermit crabs (Crustacea: Anomura: Paguroidea: Paguridae). 1. The genus Pagurus Fabricius, 1775. Journ. nat. Hist. London, 19 (4): 745-769.

Kensley, B. F., 1968. Deep sea decapod Crustacea from west of Cape Point, South Africa. Ann. South African Mus., 50 (12): 283-323.

---, 1981. On the zoogeography of southern African decapod Crustacea, with a distributional checklist of the species. Smithsonian Contributions to Zoology, 338: 1-64.

Lagardère, J. P., 1973. Distribution des décapodes dans le sud du golfe de Gascogne. Rev. Trav. Inst. Pêches marit., 37 (1): 77-95.

-_-, 1977. Recherches sur la distribution verticale et sur l'alimentation des crustacés décapodes benthiques de la Pente Continentale du Golfe de Gascogne. Analyse des groupements carcinologiques. Bull. Cent. Étud. Rech. sci. Biarritz, 11 (4): 367-440.

Lipps, J. H. \& C. S. Higkman, 1982. Origin, age, and evolution of antarctic and deep-sea faunas. In: W. G. ERnst \& V. G. Morin (eds), The environment of the deep-sea: 324-356.

MACPHERson, E., 1991. Bjogeography and community structure of the decapod crustacean fauna off Namibia (Southeast Atlantic). Journ. Crust. Biol., 11 (3): 401-415.

Manning, R. B. \& L. B. Holthuis, 1981. West African brachyuran crabs. Smithsonian Contributions to Zoology, 306: 1-379.

- \& \& - 1989. Two new genera and nine new species of Geryonid crabs (Crustacea, Decapoda, Geryonidac). Proc. Biol. Soc. Washinghton, 102 (1): 50-77.

Markle, D. F., M. J. Dadswell \& R. G. Halliday, 1988. Demersal fish and decapod crustacean fauna of the upper continental slope off Nova Scotia from La Have to St. Pierre Banks. Canadian Journ. Zool., 66: 1952-1960.

Menzies, R.J., R. Y. George \& G. T. Rowe, 1973. Abyssal environment and ecology of the world oceans. (John Wiley \& Sons, New York.)

Merret, N. R. \& N. B. Marshall, 1981. Observations on the ecology of deep-sea bottom-living fishes collected off northwest Africa $\left(08^{\circ}-27^{\circ} \mathrm{N}\right)$. Prog. Oceanogr., 9: 185-244.

PÉrès, J. M., 1985. History of the Mediterranean biota and the colonization of the depths. In: R. MARgalef (ed.), Key environments: Western Mediterranean: 198-232.

REYss, D., 1971. Les canyons sous-marins de la mer Catalane: le rech du Cap et le rech LacazeDuthiers. III. Les peuplements de macrofaune benthique. Vie Milieu, 22: 529-613.

Rice, A. L. \& R. G. Hartnoll, 1983. Aspects of the biology of the deep-sea spider crab, Dorhynchus thomsoni (Crustacea: Brachyura). Journ. Zool. London, 201: 417-431.

Rice, A. L. \& M. de Saint Laurent, 1986. The nomenclature and diagnostic characters of four north-eastern Atlantic species of the genus Munida Leach: M. rugosa (Fabricius), M. tenuimana G. O. Sars, $M$. intermedia A. Milne Edwards and Bouvier, and $M$. sarsi Huus (Crustacea, Decapoda, Galatheidae). Journ. Nat. Hist. London, 20: 143-163.

Saint Laurent, M. DE, 1985. Remarques sur la distribution des crustacés décapodes. In: L. Laubier \& C. Monniot (eds), Peuplements profonds du golfe de Gascogne: 469-478.

SARdì, F. \& I. Palomera, 1981. Crustáceos decápodos capturados durante la campaña "Mediterráneo II" (Marzo, 1977) en el Mar Catalán. Res. Exp. Cient. (Supl.). Inv. Pesq. Barcelona, 9: 143-150. 
Shelton, R. G.J. \& H. D. Dooley, 1982. New records of the geryonid crab, Geryon affinis Milne Edwards and Bouvier, and other deep water Brachyura from the northeast Atlantic. Crustaceana, 42: 108-110.

Sulak, K. J., unpubl. A comparative ecological analysis of temperate and tropical demersal deepsea fish faunas in the western North Atlantic. Ph.D. dissertation, 1984, University of Miami.

Wenner, E. L., 1982. Notes on the distribution and biology of Galatheidae and Chirostylidae (Decapoda: Anomura) from the Middle Atlantic Bight. Journ. Biol., 2 (3): 360-377.

WENNER, E. L. \& D. F. Boesch, 1979. Distribution patterns of epibenthic decapod Crustacea along the shelf-slope coenocline, middle Atlantic Bight, U.S.A. Bull. Biol. Soc. Washington, 3: $106-133$.

Zariquiey-Alvarez, R., 1968. Crustáceos Decápodos Ibéricos. Inv. Pesq. Barcelona, 32: 1-510. 